\title{
Research Paper \\ Effectiveness of Acceptance and Commitment Therapy on Self-Concept and Emotion Regulation in Children with Learning Disabilities
}

\author{
Fahimeh Ardeshiri Lordjani" ${ }^{* 1}$, Tayebeh Sharifi ${ }^{2}$ \\ 1. Ph.D. Student of Psychology, Shahrekord Branch, Islamic Azad University, Shahrekord, Iran \\ 2. Assistant Professor, Department of Psychology, Shahrekord Branch, Islamic Azad University, Shahrekord, Iran
}

Citation: Ardeshiri Lordjani F, Sharifi F. Effectiveness of acceptance and commitment therapy on self-concept and emotion regulation in children with learning disabilities. Quarterly Journal of Child Mental Health. 2019; 6(3): 28-39.

http://dx.doi.org/10.29252/jcmh.6.3.4

\section{A R T I C L E I N F O}

\section{Keywords:}

Acceptance and commitment therapy

(ACT), self-concept, emotional regulation, learning disability

Received: 8 Feb 2018

Accepted: 21 Jun 2018

Available: 9 Nov 2019

\section{A B S T R A C T}

Background and Purpose: Learning disability is among the problems which have long been attended to by the specialists and child psychologists. Despite having normal intelligence, children with learning disorders cannot have appropriate educational promotion in reading, writing, and mathematics. This process not only damages their educational performance, but it also influences their psychological processes and causes them to have lower self-concept and self-esteem and vulnerable emotional regulation. Therefore, the purpose of the present study was to investigate the effectiveness of acceptance and commitment therapy (ACT) on self-concept and emotional regulation of children with learning disability.

Method: It was a quasi-experimental research with pretest- posttest control group design. The study population of the present study included all primary students with learning disability who referred to consultation centers in Isfahan in the academic year 2017-2018. A sample of 30 children from them was selected through purposeful sampling and assigned either to the experimental or control group. The instruments used in the present study included Learning Problems Questionnaire (Wilcot, et al, 2011), Emotion Cognitive Regulation Strategies (Garenfski, et.al, 2002) and Children's Self-concept (Piers-Harris, 1969). The experimental group received the acceptance and commitment therapy (ACT) in nine sixty-minute training sessions during two months. The data were analyzed through ANCOVA via SPSS23 software.

Results: The results showed that ACT has had significant effect on self-concept $(\mathrm{F}=13.77$, $\mathrm{P}<0.0001)$, positive emotional regulation $(\mathrm{F}=154.65, \mathrm{P}<0.0001)$ and negative emotional regulation $(\mathrm{F}=105.17, \mathrm{P}<0.0001)$ in the children with learning disability. It means that ACT had led to the improvement of self-concept and positive emotional regulation of the children with learning disability and decreased their negative emotional regulation.

Conclusion: According to the findings of the present study, it can be said that ACT can be applied as an efficient method to improve self-concept and emotional regulation of children with learning disability through making values clear and psychological flexibility. Furthermore, ACT improves other cognitive and emotional processes such emotional regulation in children with learning disabilities.

\footnotetext{
* Corresponding author: Fahimeh Ardeshiri Lordjani, Ph.D. Student of Psychology, Shahrekord Branch, Islamic Azad University, Shahrekord, Iran.

E-mail addresses: Ardeshiri2020@gmail.com
} 


\section{اثربخشى درمان مبتنى بر يذيرش و تعهد بر خودينداشت و تنظيم هيجانى كود كان مبتلا به ناتوانى يادكيرى \\ فهيمه اردشيرى لردجانى *'، طيبه شريفى

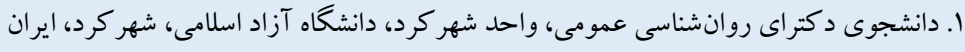

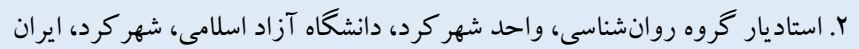

\section{جكيده}

زمينه و هدف: ناتوانى هاى يادگيرى از جمله مشكلاتى هستند كه از ديرباز مورد توجه متخصصان و روانشناسان حوزه كودك بودهاند. كود كان مبتلابه اين اختلال با وجود هوش بهنجار، قادر به بيشرفت تحصيلى در زمينههاى خواندن، نوشتن، و رياضيات نيستند. اين وضعيت سبب مىشود تا اين كود كان از خودينداشت و حرمت خود يايين و تنظيم هيجانى يايينى برخوردار باشند؛ بنابراين هدف از يُوهش حاضر بررسى اثربخشى درمان مبتى بر يذيرش و تعهد بر خودينداشت و تنظيم هيجانى كود كان داراى ناتوانى ياد كيرى بود.

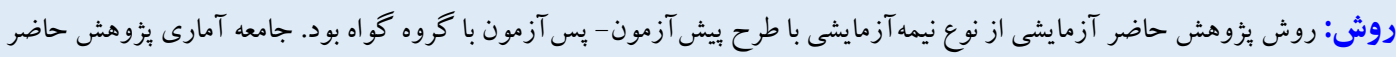
شامل تمامى دانش آموزان دبستانى مبتلا به ناتوانى يادگيرى مراكز مشاوره شهر اصفهان در سال تحصيلى

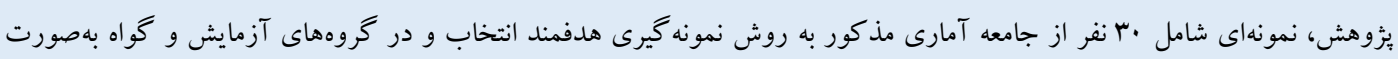

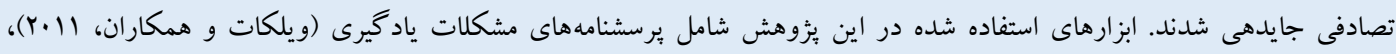

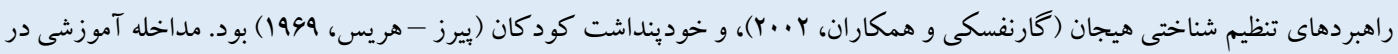
طى 9 جلسه آموزشى •ودقيقهاى در طول Y ماه فقط براى گروه آزمايش انجام شد و در يايان دادههاى به دست آمده با استفاده از آزمون تحليل كوواريانس مورد تجزيه و تحليل قرار گرفت.

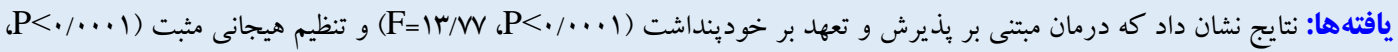

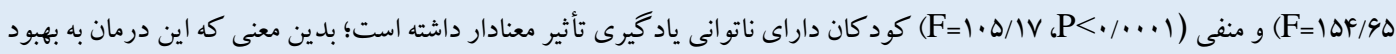
خودينداشت و تنظيم هيجانى مثبت كود كان داراى ناتوانى يادگيرى و كاهش تنظيم هيجانى منفى آنها منجر شده است. نتيجه كيرى: بر اساس يافته يُوهش حاضر مى توان كفت درمان مبتى بر يذيرش تعهد با آشكار ساختن ارزشها و عمل متعهدانه و ايجاد

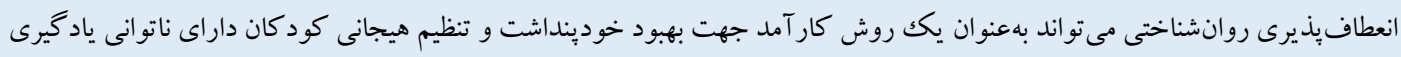

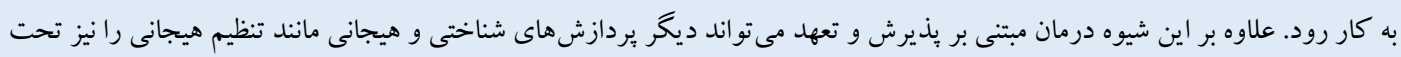
تأثير مثبت قرار دهد.
مشخصات مقاله

كليدوازهها:

درمان مبتنى بر بذيرش و تعهل،

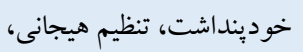
ناتوانى ياد گيرى
دريافت شده: 99/11/19 - 9 - 9 9 يذيرفته شده: آس/T.T منتشر شده: \$

* نويسنده مسئول: فهيمه اردشيرى لردجانى، دانشجوى دكتراى روانشناسى عمومى، واحد شهر كرد، دانشكاه آزاد اسلامى، شهر كرد، ايران.

رايانامه: Ardeshiri2020@gmail.com

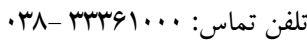


ازهم گسيختخى در روابط بين فردى ( • (1)، نارسايى در بردازش اطلاعات

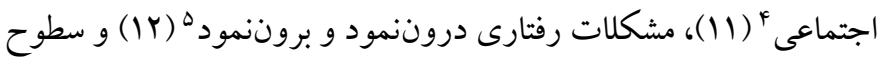

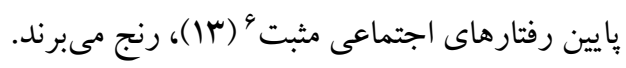

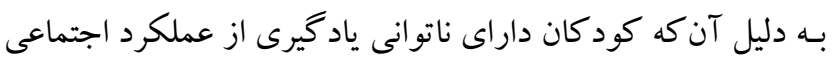
و تحصسيلى بايينى برخوردارند، درك تحصيلى آنها از خود بايين بوده و همين موضــوع بر خودينداشــت V آنان تأثير منفى مى كذارد (IF) و در

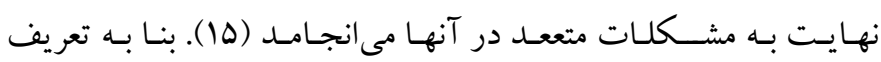
خودينداشت بهعنوان تصورى است كه كود كان درباره خودشان دارند و اين تصسور از طريق بـسخوراندهاى دريافتى از سـوى همسـالان كودك، والدين و معلمان، و ارزيابى كودكك از تجارب ذهنىاش شـكل مى گيرد (19). مى توان كفـت خودينـداشـت آموختنى بوده و جنانجه در مســير شكل گيرى مؤلفه هاى روانشناختى، آسيبى به اين ويز گیى كود كان وارد آيد، با به كار گيرى روشهاى آموزشى صحيح مى توان آن را افز ايش داد

كود كان داراى ناتوانى ياد كيرى علاوه بر خودينداشت، در فرايندهاى هيجانى همجيون تنظيم هيجان^يز داراى مشكلاتى هستند (11 و 19). بنا بـه تعريف، تنظيم هيجان به فرايندهايى اطلاق مىشــود كه از طريق آنها افراد هيجاناتشان را براى ياسخ به توقعات محيطى بهطور هشيار و ناهشيار

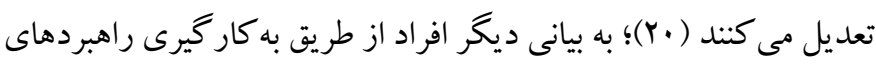

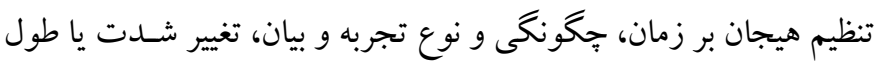
دوره فراينـدهـاى رفتارى و تجربى و يا جســمانى هيجانها، بهصــورت خود كار يا مهار شده و هوشيار انه يا ناهوشيار، به تنظيم هيجان مى بردازند

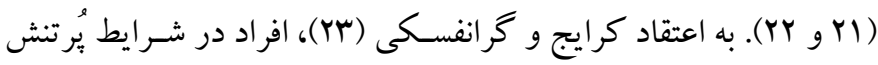
بـهـصــورت متفــاوت عمـل مى كنند؛ برخى از آنان به ســـرزنش خود و و سرزنش ديكران"'، نشخوار فكرى" '، و فاجعهانگًارى با دست مىزنند كه اين كـار بـاعـث افزايش هيجـان منفى و نـاكوار جلوه نمودن موقعيـت

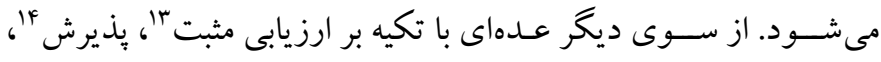

8. Emotional regulation 9. Self-blame

10. Blaming others

11. Rumination

12. Catastrophising

13 .Positive reappraisal

14. Acceptance
مقلدمه

ناتوانى ياد گيرى' يكى از مهم ترين مشكلات در فر ايند يادگيرى به شمار مىرود. درواقع مى توان كفت اين اختلال يكك اصطلاح كلى است كه در آن فرايندهاى شـناختى يايه كه در فهميدن يا اسـتفاده از زبان شـفاهى و نوشتارى نقش دارند، دجّار مشكل شده و بهصورت ضعف در اكتساب و اســفــاده از مهارت هايى نظير صـسحبت كردن، گوش كردن، خواندن، نوشـتن، توانايى هاى رياضـى، و اسـتدلال كردن آشـكار مى شـوند (1). يثوهشخران متعدد بر اين اعتقادند كه علت زيربنايى بسيارى از مشكلات

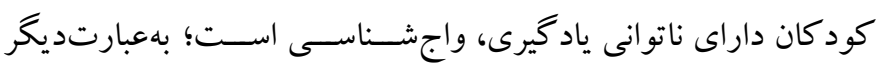
كودكـان داراى اين اختلـال از خزانسه واز كان اندكى برخوردارند كه آن هم محدود به كلمات كو تاهو يربسـامد اسـت. همجينين بنا به كزارشها، مشـكلات معنايى از جمله دانش معنايى محدود و ضــعف در طبقهبندى كلمات در مقولههاى معنايى، بر مشكل كوجّك بودن خزانه واز كانى نيز

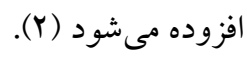

مهم ترين علـت عملكرد تحصــيلى ضــيف، مربوط بـه ناتوانىهاى يـاد گيرى اسـت و هرسـالـه بـه اين دليل تعداد زيادى دانش آموزان در فراگيرى مطالب درسى با دشوارى مواجه مى شوند. با وجود اينكه هوش اين دانش آموزان معمولاً در دامنه متوسط يا بالاتر قرار دارد، ولى نسبت به سـاير دانش آموزان در شـرايط يكسـان آموزشـى، از عملكرد تحصـيلى ضسعيفترى برخوردار هسـتند. از سـوى ديخر اين افراد با توجه به فقدان ضايعات بيولوزيك بارز، عدم مشكلات اجتماعى و روانى حاد و با وجود برخوردارى از محيط آموزشـى مناسـب و دارا بودن هوش متوسـط، در زمينههاى خاص تحصــلى (خواندن، نوشــتن حســاب كردن)، قادر به ياد گيرى نيستند (r) (ب). يخوهشهـاى گوناكون حاكى از آن هســتند كه دانش آموزان داراى

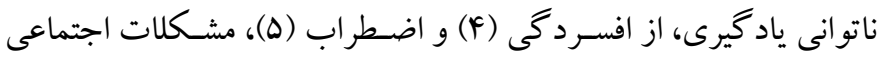
(9)، مهارت هاى بينفردى ضــعيف (V)، ســوح بالاى طرد اجتماعى بو و

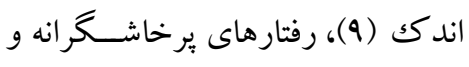

1. Learning disability

2. Social rejection

3. Interrelationship dissociation

4. Social information processing deficiency

5. Internalizing -externalizing problems

6. Positive behaviors

7. Self-concept 
بهسوى اهداف رفتارى سوق دهد (روشنسازى ارزشها). مرحله آخر نيز

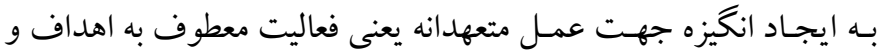

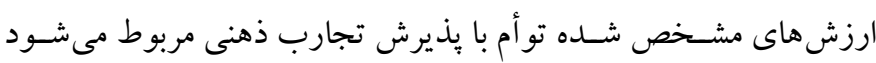

حـال بـا توجـه بـه بيـامـدهـاى نامطلوب ناتوانى ياد گيرى و تأثيرات

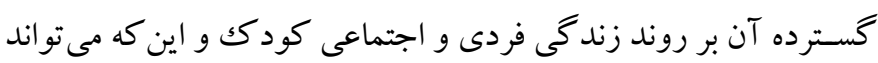

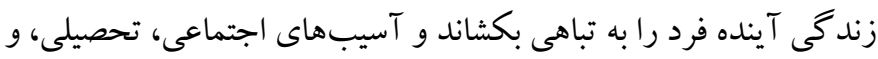

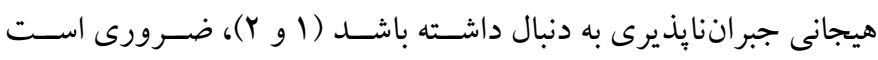

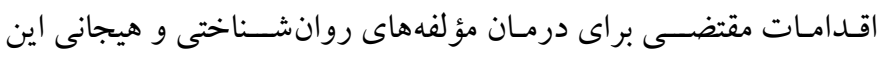
كود كان در كنار روشهاى آموزشى و تحصيلى مناسب به كار خر فته شود

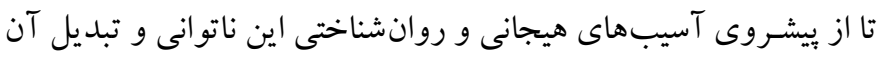

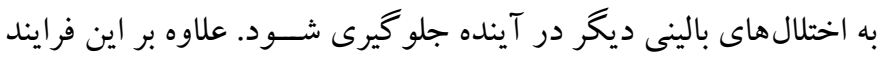

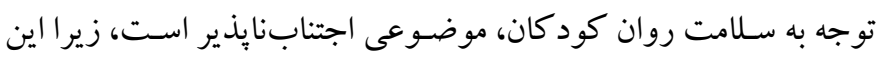

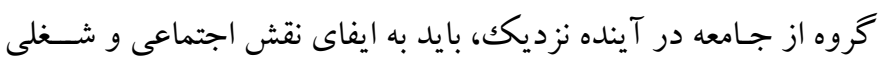

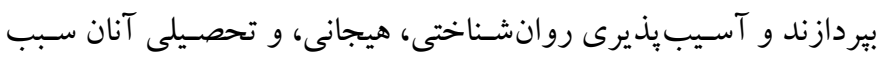

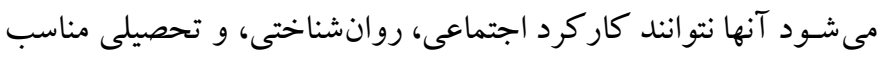

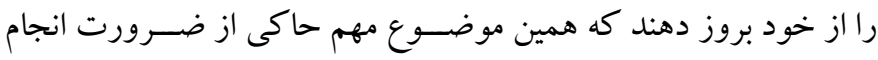

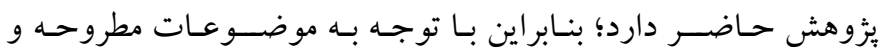

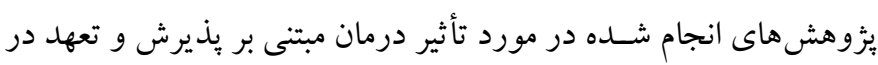

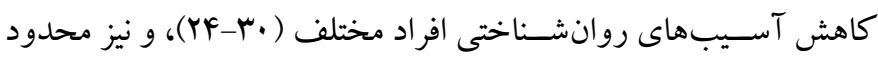
بودن انجام مطالعات درباره اثربخشسى درمان مبتى بر يذيرش و تعهل بر

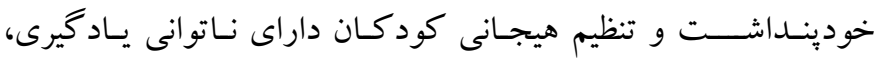

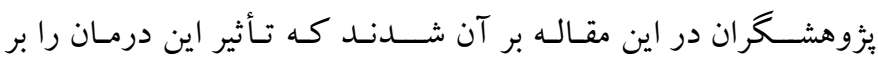

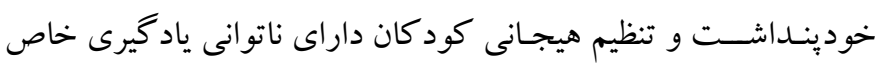
مورد بررسى و آزمون قرار دهند.

روش

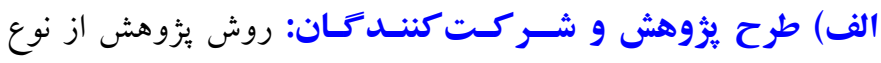

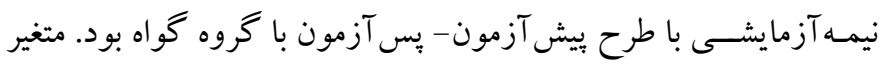

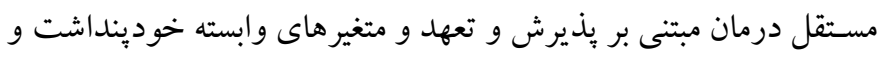

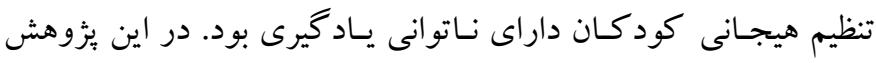

3. Putting in to perspective

4. Acceptance and Commitment Therapy (ACT)

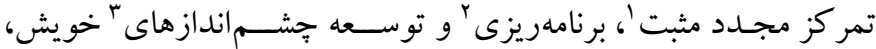
هيجان ايجاد شـــهـ را مديريت كرده وتو انشــان را جهـت مقابله با آن بالا

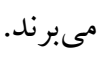
بهمنظور اصــلاح و ارتقاى مؤلفههاى روانشـــاختى كود كان داراى

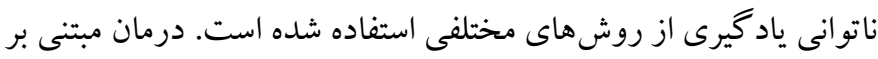

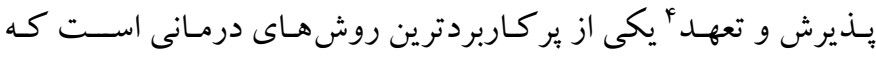
كارايى بالينى خود را در يزوهشه هايى مانند مطالعات طيبى، محمدخانى،

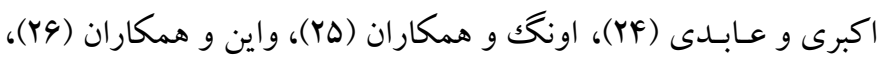

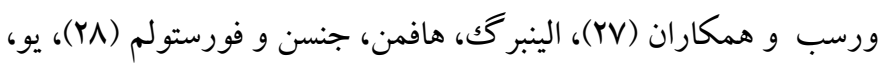
نورتون و مكك كراكن (Yq)، و كروسبى و توهيخك (·r) نشان داده است.

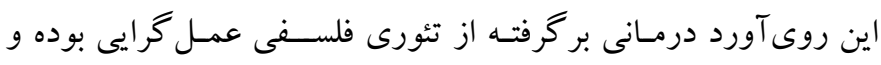

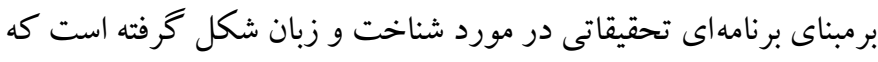
نظريه جارجوب رابطههاى ذهنى خو انده مى شود ( آم).

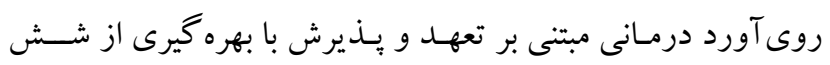

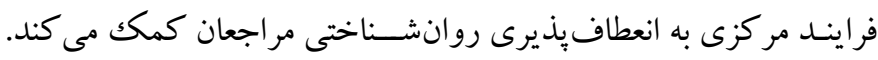

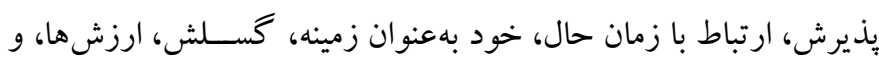

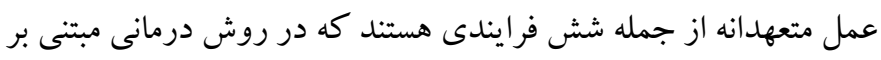

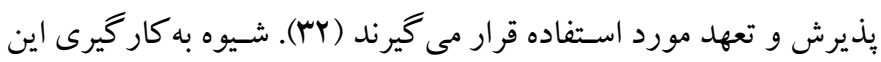
فر ايندها به اين شرح است: در ابتداى درمان سعى بر آن است كه بذ بذيرش

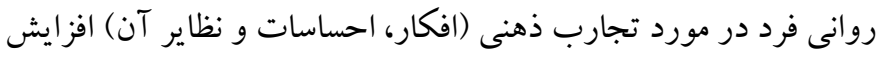
و در مقـابـل اعمـالى كـه مهار گرىى نامؤثر را به دنبال دارد، كاهش ئه يابد.

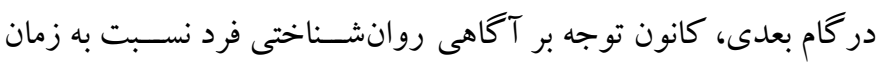

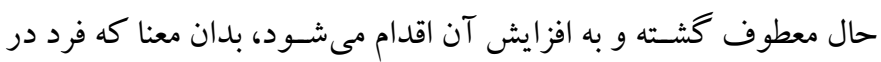

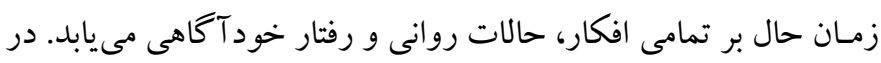
مرحله سـوم هدف، جداسـازى فرد از تجارب ذهنىاش است (جداسازى

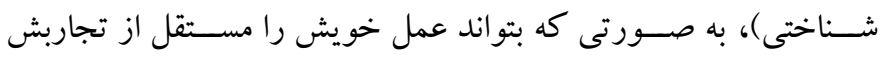

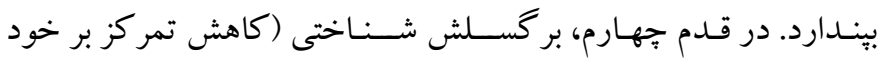

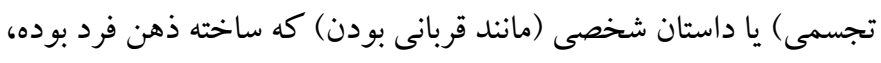

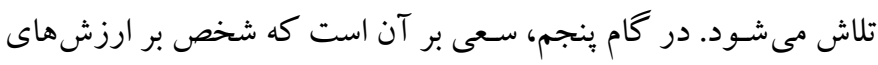
فردى و اصلى خود وقوف يافته، بهطور واضـح آنان را مشخص كرده و 


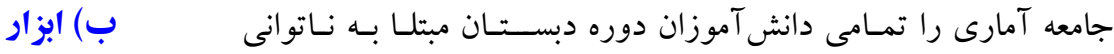

ا. برسشسنامه مشكلات يادكيرى': برسشنامه مشكلات يادگيرى كلورادو

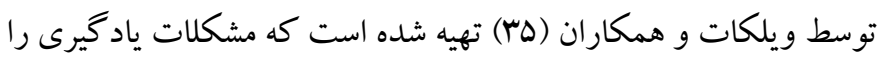

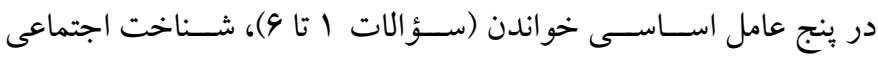

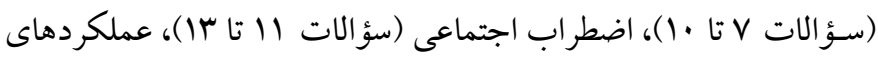

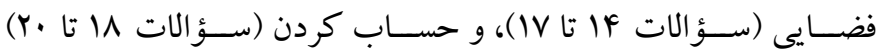
مى سنجد. اين برسشنامه كه از ·r كويه تشكيل شده است، توسط والدين دانش آموزان تكميل مىشـود. ياسخ به هر عبارت در يكك مقياس ليكرت

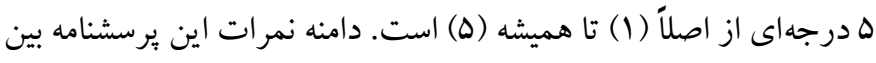

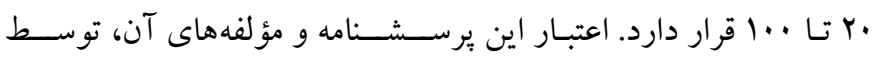

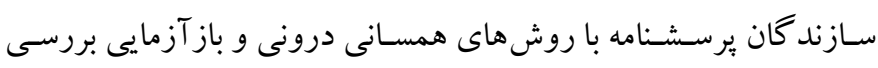

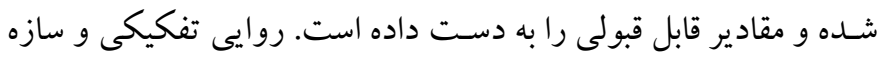

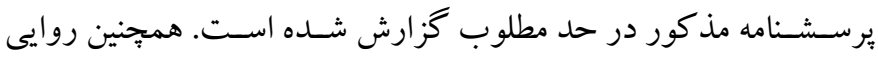

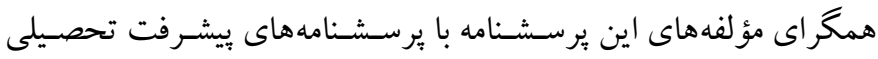

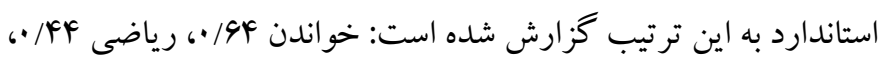

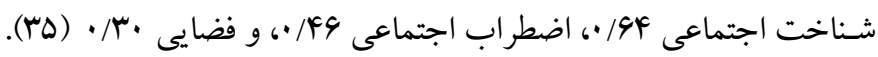
در يزوهش صــبحى، حـاجلو و غلـامزاده (4)، بهمنظور وارسـى اعتبار

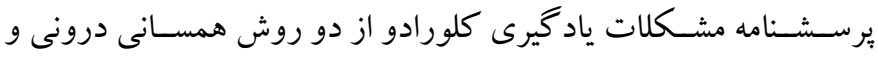

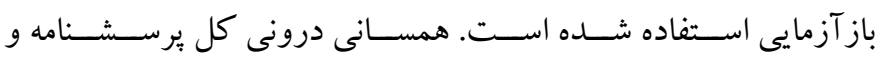

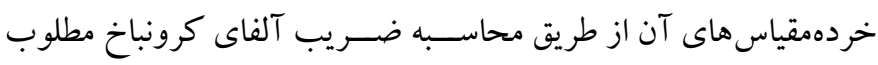

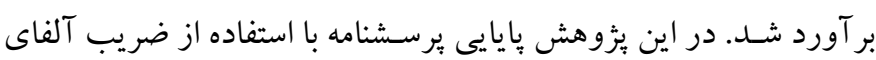

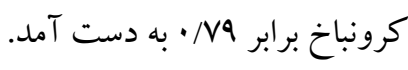

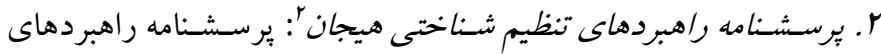

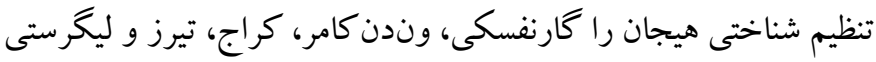
در سـال Y . P. به منظور ارزيابى راهبردهاى شناختى تطابقى بعد از تجربه

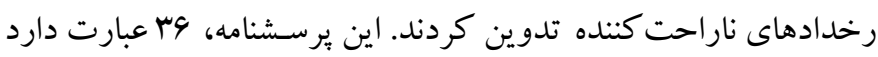

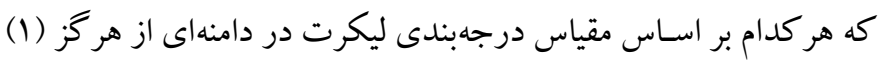

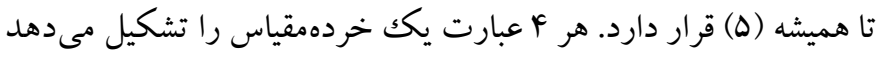

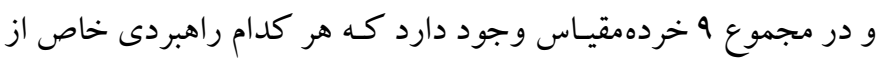
راهبردهاى تنظيم شـناختى هيجان را مىسـنجد. خر دهمقياس ها عبارتاند

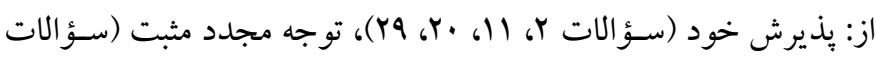

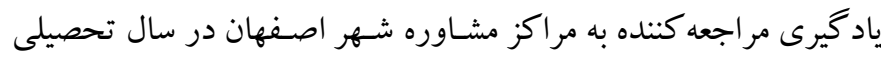
هوا هدفمند استفاده شد. بهاينصورت كه از بين مراكز مشاوره شهر اصفهان،

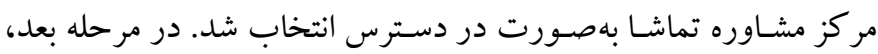

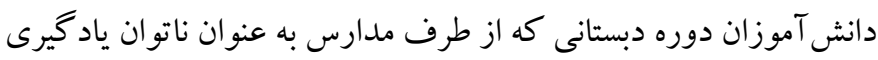

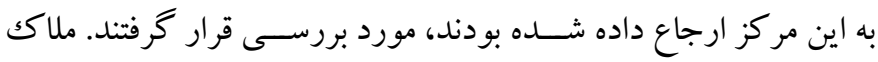

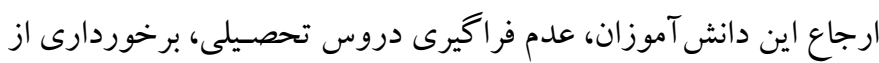

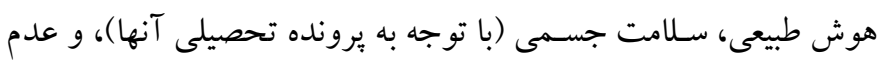

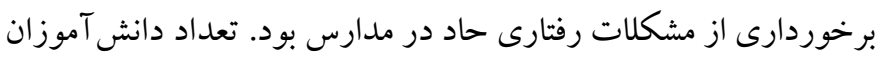

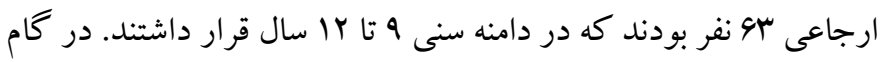

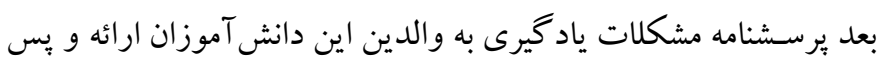

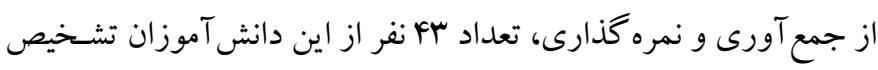

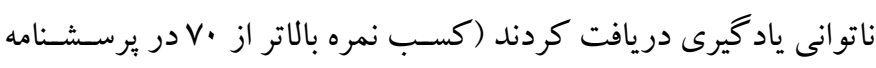

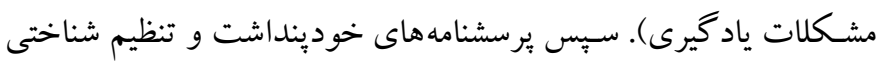

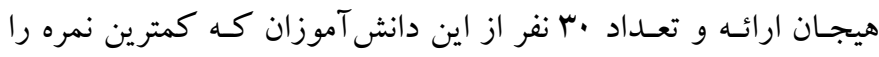

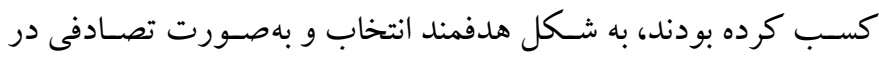

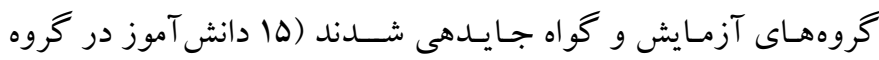

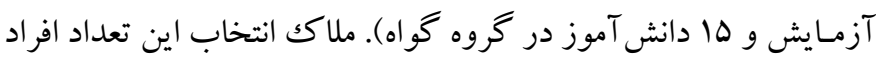

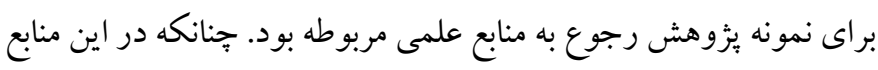

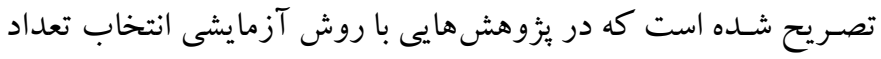

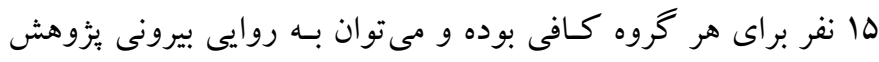

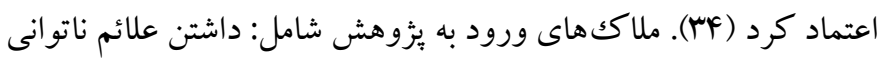

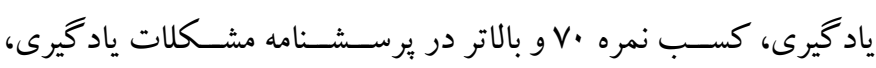
برخوردارى از سـلامت جسمى، و عملكرد انضباطى مناسب بود. همجينين

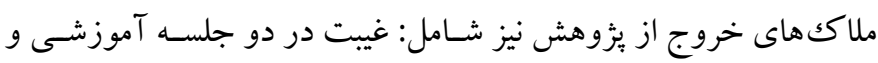

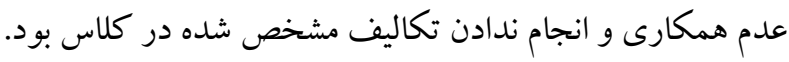

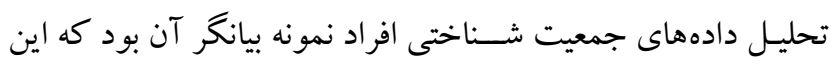

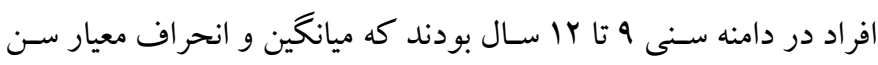

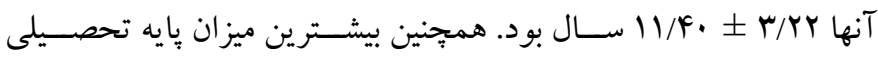

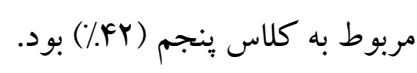


A. احسـاس فرد نسبت به خودش، به كار مىرود. اين برســــامه شـامل سؤال است كه سؤالات برسشنامه بهصورت گزارش شخصى درباره اينكه

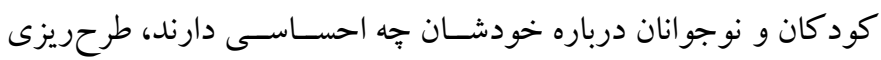

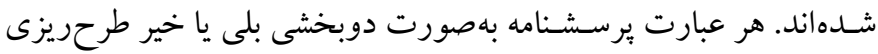
شــده اسـت. اين مقياس 9 بعد دارد: رفتار، وضسعيت مدرسـه وضسعيت

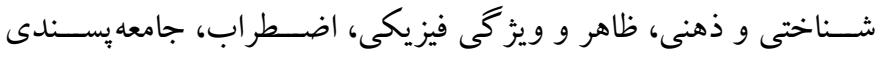

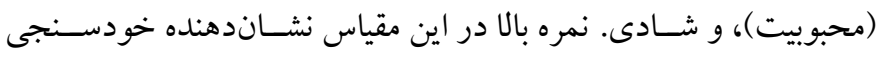

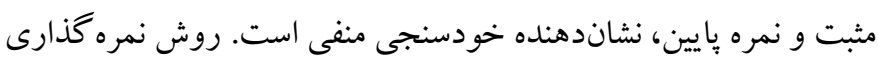

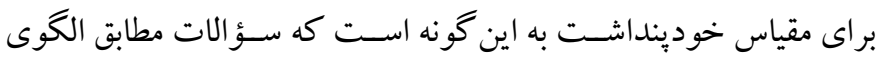
نمره كذارى در جهت خودينداشـت بالا (كافى)، نمره داده مى شــوند. از

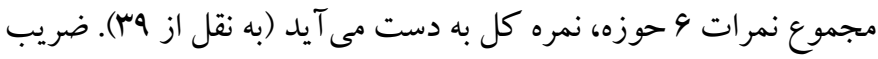

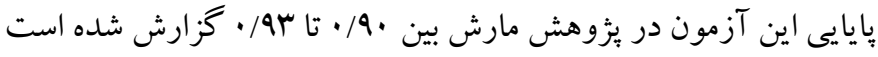

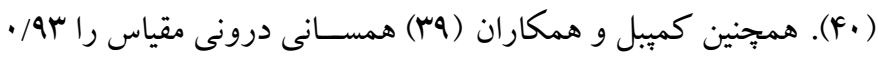

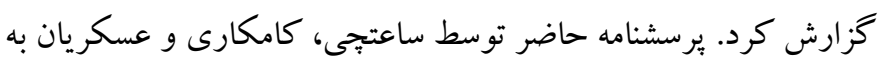

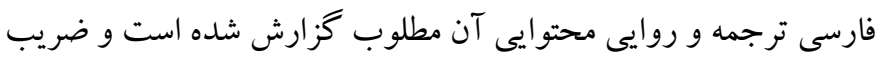

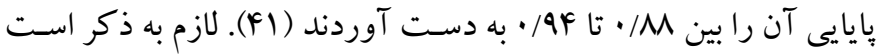

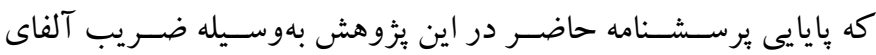

$$
\text { كرونباخ • /9 • محاسبه شد. }
$$

ج) برنـامـهـ مداخلهاى: در يزوهش حاضــر جلســات درمان مبتنى بر يذيرش و تعهد در طى 9 جلسه ·9 دقيقهاى بهصورت هفتهاى يكك جلسه

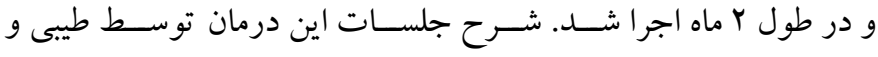
همكاران (YF) طر حريزى و اجرا شــده اسـت. رئوس مطالب جلســات درمانى در جدول آ آورده شده است.

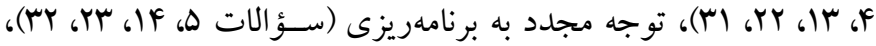

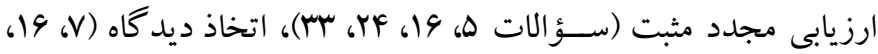

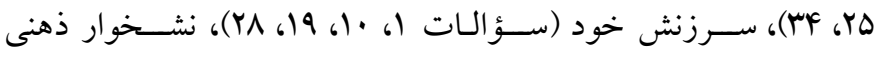

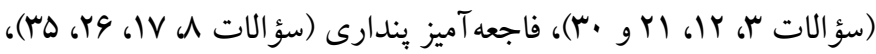

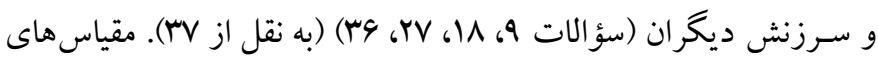
اين يرسـشــنامه به دو قسـمت عمده عامل هاى تنظيم شــناختى مثبت و عامل هاى تنظيم شـناختى منفى تقسيمبندى مى شود كه اين دو عامل بايد

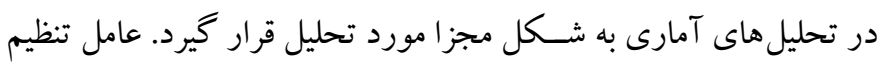

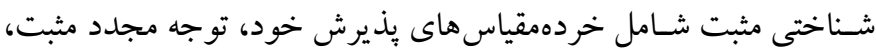

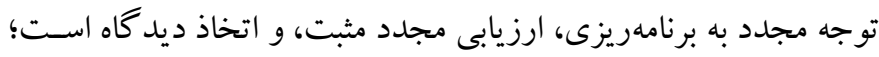

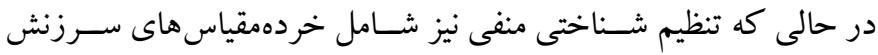

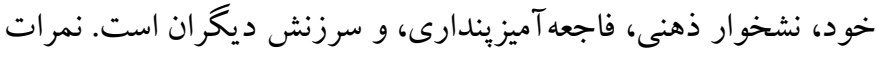

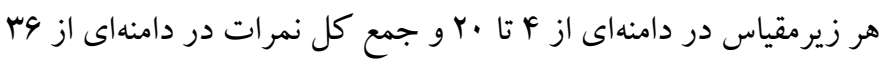

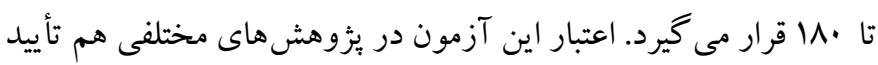

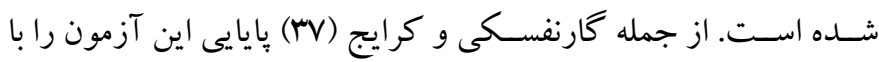

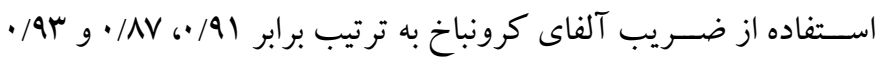

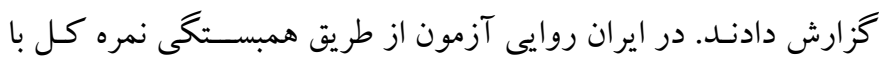

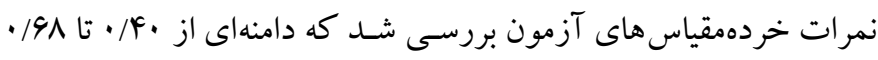

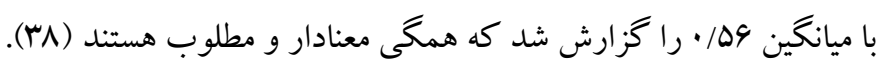

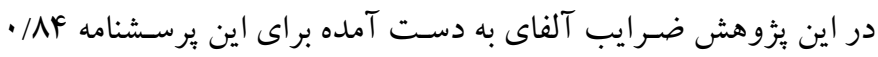

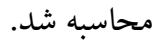
"r. يرسشنامه خوديند/شت كودكان ': مقياس خودينداشت كود كان توسط ييرز - هريس در سـال 1999 تهيه شـده اسـت. اين مقياس جهت سـنجش

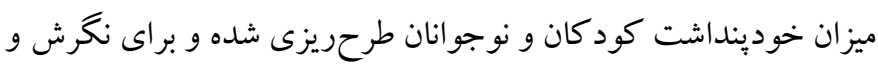


سنجش عملكرد، مرور تكليف، قوانين مسير فرزند يُرورى استعاره (اداره يرخرج و مرج)، مثال تخممرغ خراب و سالم در مورد تحكيم قوانين و ساختار خانواده، ايجاد

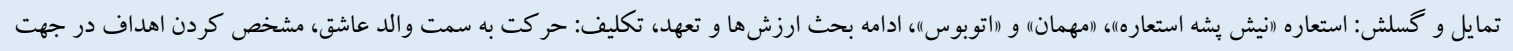

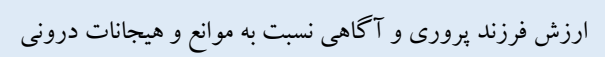

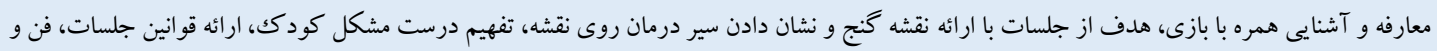

\section{جمعبندى}

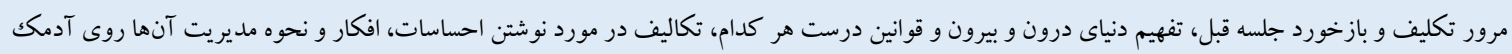

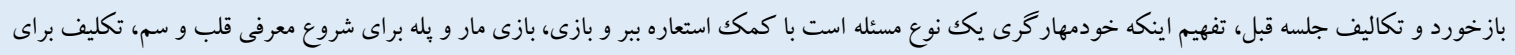
درست كردن جعبه سم و قلب و نوشتن ببرهايى كه سراغ كودك مكى مئك آيند.

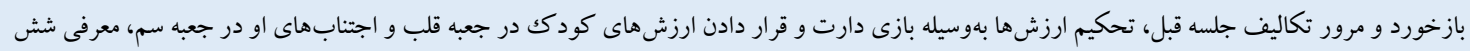

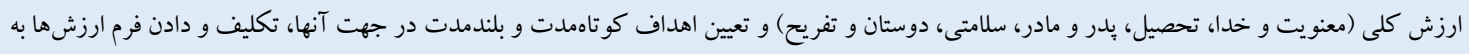

كودك.

بازخورد و بررسى تكاليف جلسه قبل، گسلش و استعاره اتوبوس، تمايل و استعاره راديو، تكليف يافتن مسافران مزاحم و باطل كردن قراردادها با آنها

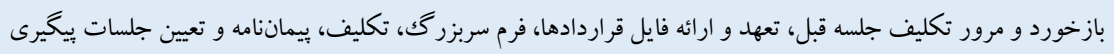

به والدين و شش جلسه بعدى مربوط به كود كان داراى ناتوانى ياد كيرى

در اين بثروهش براى تجزيهوتحليل دادهها از دو سطح آمار توصيفى وهى و اسـتنباطى اسـتفاده شـده اسـت. در سـطح آمار توصسيفى از ميانخين و انحر اف استاندارد و در سـطح آمار اسـتنباطى از آزمون شـاييرو -ويلك جهـت بررســى نرمـال بودن توزيع متغيرهـا، آزمون لوين براى بررسـى برابرى واريانس ها، همجينين از تحليل كواريانس براى بررسـى فرضــيه يثزوهش استفاده شد. لازم به ذكر است كه دادههاى به دست آمده در اين مطالعه با استفاده از نرمافزار آمارى بr - SPSS مورد تجزيهوتحليل قرار كرفته است.

مافتها

يافته هاى توصـيفى يزوهش شــامل ميانخين و انحر اف معيار و همجينين نتايج مربوط به نرماليتى در جدول Y خزارش شده است.
د) روش اجرا: جهت انجام يثوهش، ابتدا هماهنگى هاى لازم با مسئولين مركز مشـاوره تماشا به عمل آمده و يس از انتخاب افراد نمونه با رضايت كتبى (از والـدين) و گمـارش آنهـا در گروههـاى آزمـايش و گواه،

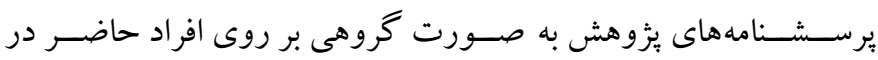
يثزوهش اجرا شــــ. جهـت رعايت اخلاق در بزوهش رضــايت اولياء و دانش آموزان براى شــركت در برنامه مداخله كســبـ و از كليه مراحل مداخله آكاه شدند. همجنين به افراد گرووه گواه اطمينان داده شد كه آنان نيز بس از اتمام فرايند يزٔوهشــى اين مداخلات را دريافت خواهند كرد. در اين مطـالعه به افراد هر دو كرووه اطمينان داده شـــد كه اطلاعات آنها محرمانه باقى مى ماند و نيازى به درج نام نيست. در نهايت، بر روى گروه آزمايش مداخله آموزشـى با توجه به محتواى ارائه شـده در جدول يك اجرا شــد، درحسالى كـه افراد گرووه گواه به همان روش جارى و معمول آموزش مىديدند. للازم به توضسيح است كه سه جلسه اول مداخله مربوط

جدول r: نتايج آمار توصيفى در مراحل ييش و يسآزمون

\begin{tabular}{|c|c|c|c|c|c|c|c|}
\hline \multirow{2}{*}{ نوماليتى دادهها } & \multicolumn{2}{|c|}{ يس آزمون } & \multirow{2}{*}{ نرماليتى دادهها } & \multicolumn{2}{|c|}{ يِيش آزمون } & \multirow{2}{*}{ كروهها } & \multirow{2}{*}{ مؤلفه ها } \\
\hline & انحراف معيار & ميانكين & & انحر اف معيار & ميانكين & & \\
\hline.$/ 11$ & $\Delta / \wedge \varphi$ & $\Delta r / V T$ & $\cdot / r Y$ & $\Delta / T V$ & $r q / f$. & تنظيم هيجان مثبت & \multirow{4}{*}{ كروه آزمايش } \\
\hline$\cdot / r r$ & $f / \Delta \Lambda$ & $r_{1 / Y q}$ &.$/ 11$ & $f / q F$ & FI/RT & تنظيم هيجان منفى & \\
\hline . & $\Delta / \Delta F$ & $r \Delta / A$. & $\cdot / r$. & $\Delta / 9 V$ & $r q / 9$. & خودينداشت & \\
\hline.$/ 1 f$ & $F / I V$ & $r \mid / r$. & ./Ir & $r / v i$ & $4 \cdot 194$ & تنظيم هيجان مثبت & \\
\hline$\cdot / r$. & $F / N$ & $r q / r^{q}$ &.$/ 19$ & $r / r \Delta$ & $r \cdot / r$. & تنظيم هيجان منفى & \multirow{2}{*}{ كروه گُواه } \\
\hline.$/ \mathrm{VV}$ & $\Delta / 19$ & $r 9 / 94$ & 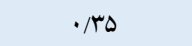 & F/A & rN/G. & خودينداشت & \\
\hline
\end{tabular}


فرض همكنى شـيب خط رگرسـيون در متغير هاى خودينداشـت و تنظيم شناختى هيجان مثبت و منفى، برقرار بوده است. نتايج تحليل كوواريانس تأثير عضسويت كروهى بر ميزان خودينداشـت و تنظيم شــاختى هيجان مثبت و منفى كود كان داراى ناتوانى ياد كيرى با كنترل متغير بيش آزمون در جدول م گزارش شده است. لازم به ذكر است كه متغير خودينداشت به دليل شــيوه نمره كذارى متفاوت و مبانى نظرى مجزا نســبت به تنظيم شـــــاختى هيجـان مثبـت و منفى بـه شـــــل همزمان با اين متغيرها مورد تجزيهوتحليل قرار نخرفت، بلكه اين تحليل ها به شكل جدا از هم صورت يذيرفته و نتايج صـرفاً جهت سـادهتر و قابلفهمتر شــدن در يكك جدول ارائه شده است.
براى بررسى تفاوت شـاخص هاى توصسيفى در سـطح اسـتنباطى از تحليـل كوواريانس اســتفاده شــــ كه قبل از ارائه نتايج، يِيشفرض هاى آزمونهاى يار امتريك مورد سـنجش قرار كرفت. بر همين اسـاس نتايج

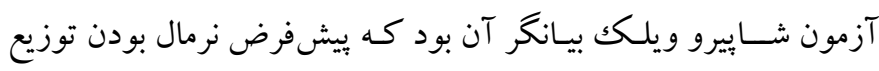

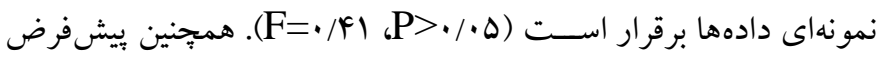
همكنى واريانس نيز توســـ آزمون لوين مورد ســنجش قرار كرفت كه

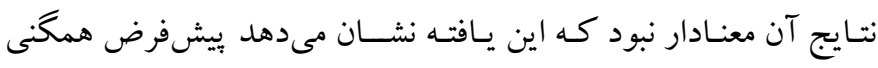
واريانسها رعايت شده است (ه •/P>). همجنين بايد اشاره كرد كه در بررسى بيشفرض همكنى شيب خط رگر سيون، نتايج نشان داد كه تعامل بيش آزمون بـا متغير كروهبنـدى در متغيرهـاى خودينـداشـــت و تنظيم شـناختى هيجان مثبت و منفى معنادار نبوده اسـت. اين بدان معناسـت كه

جدول بّ: نتايج تحليل كوواريانس آموزش درمان مبتنى بر يذيرش و تعهد بر خودينداشت و تنظيم هيجانى كودكان داراى ناتوانى ياد

\begin{tabular}{|c|c|c|c|c|c|c|c|c|}
\hline توان آزمون & اندازه اثر & سطح معنادارى & $\mathbf{F}$ & ميانكين مجذورات & درجه آزادى & مجموع مجذورات & كروه & متغير \\
\hline$\cdot / 9 V$ & $\cdot / \mathrm{TV}$ & $\cdot / \cdot 1$ & $19 / 49$ & IrG/YF & 1 & IYG/YF & همير اش & \multirow{4}{*}{ نظيم هيجان مثبت } \\
\hline \multirow[t]{2}{*}{1} & \multirow[t]{2}{*}{$\cdot / \wedge \Delta$} & \multirow[t]{2}{*}{$\cdot / \cdots 1$} & \multirow[t]{2}{*}{$10 F / 9 \Delta$} & IrVV/A. & 1 & IrVV/A. & بين گروهى & \\
\hline & & & & N/YG & rV & $r r r / \cdot \Lambda$ & خطا & \\
\hline 1 & .191 & $\cdot / \cdots \cdot 1$ & Fr/AG & $r ৭ 9 / \mu r$ & 1 & $r ৭ 9 / \mu r$ & همبر اش & \\
\hline \multirow[t]{2}{*}{1} & \multirow[t]{2}{*}{$\cdot / \mathrm{va}$} & \multirow[t]{2}{*}{$\cdot / \cdots 1$} & \multirow[t]{2}{*}{$1 . \Delta / I V$} & $V M F / F \Delta$ & 1 & $V M F / F D$ & بين گروهى & \multirow{2}{*}{ تظيم هيجان منفى } \\
\hline & & & & $9 / 91$ & rV & IMN/DF & خطا & \\
\hline .191 &.$/ 1 \Lambda$ & /.r & $9 / \pi 1$ & $\mid \Delta r / \cdot F$ & 1 & $1 \Delta r / \cdot F$ & همير اش & \\
\hline \multirow[t]{2}{*}{.$/ 90$} & \multirow[t]{2}{*}{. } & \multirow[t]{2}{*}{.$/ .1$} & \multirow[t]{2}{*}{$1 \pi / \mathrm{VV}$} & 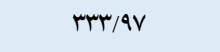 & 1 & $M T r / 9 V$ & بين گروهى & \multirow[t]{2}{*}{ خودينداشت } \\
\hline & & & & $Y F / Y F$ & rV & $90 F / 99$ & خطا & \\
\hline
\end{tabular}

داراى ناتوانى يادگيرى، افزايش و تنظيم شــناختى هيجان منفى، كاهش

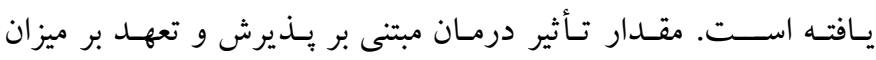
خودينـداشــت و تنظيم شـــــاختى هيجـان مثبت و منفى كود كان دار اي .

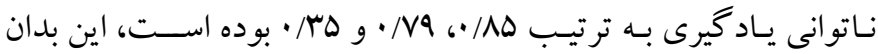

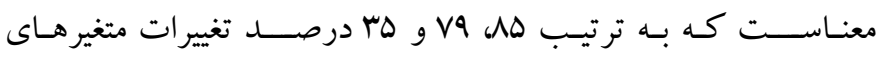
خودينــاشــت و تنظيم شـــــاختى هيجـان مثبت و منفى كود كان داراى نـاتوانى ياد گيرى توســط عضــويت گروهى (درمان مبتنى بر بذيرش و

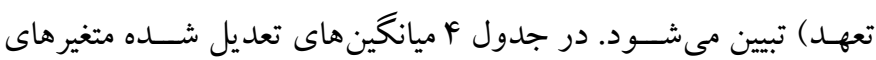
وابسته گزارش شده است.
با توجه به نتايج جدول لا، آموزش متغير مسـتقل (درمان مبتنى بر يذيرش و تعهد) ايجاد تفاوت معنادار ميانخين نمرات متغيرهاى وابسـته (خودينـداشــت و تنظيم شــناختى هيجان مثبت و منفى كود كان داراى ناتوانى يادگيرى) در مرحله يس آزمون در سـطح خطاى ه / • منجر شده اسـت؛ بنابر اين نتيجه مىشـود كه با كنترل متغيرهاى مداخله گر، ميانگين نمرات متغيرهاى خودينداشــت و تنظيم شــناختى هيجان مثبت و منفى كودكـان داراى نـاتوانى ياد گيرى با درمان مبتنى بر بذيرش و تعهد تغيير يافته اسـت. اين تغيير بدين شـكل بوده اسـت كه مطابق با يافته توصيفى، يس آزمون نمرات خودينداشـت و تنظيم شـناختى هيجان مثبت كود كان 
به تغيير روابط با تجارب درونىشـان و كاهش اجتناب تجربى برداخته و

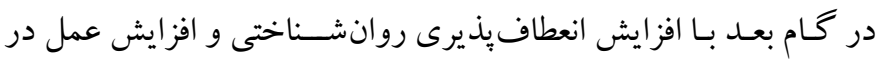

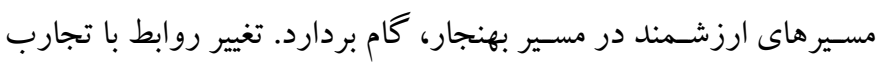

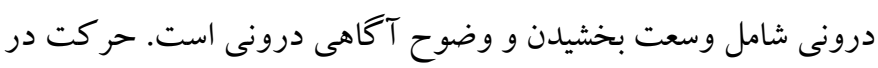

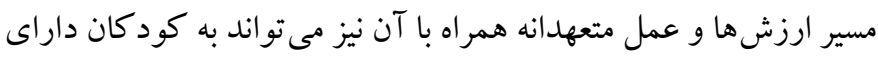

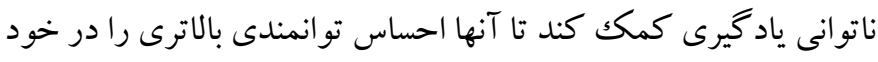

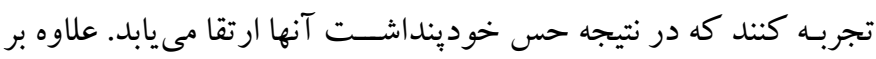

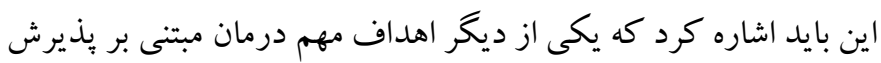

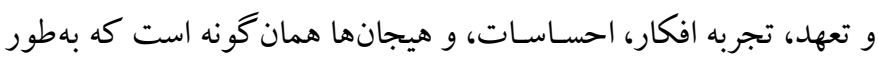

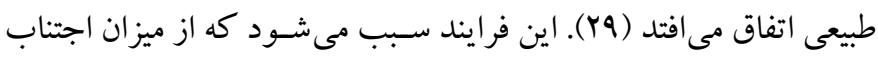

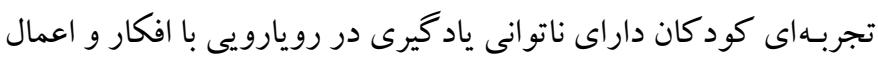
ناتوانسازى همجيون مو اجهه با تكليف درسى جديد، كاسته شود.

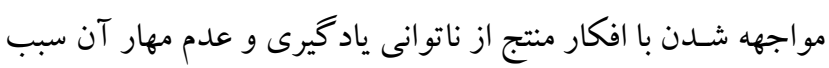

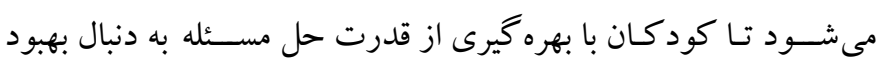

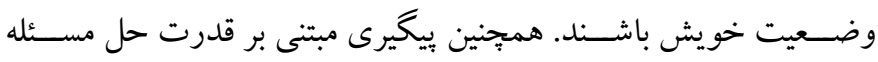

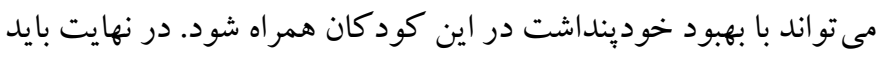
توجه داشت كه درمان مبتنى بر يذيرش و تعهل بر افزايش عمل ارزشمند

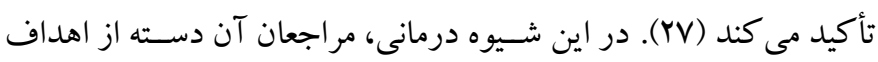

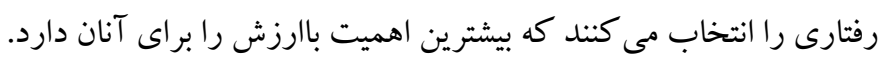

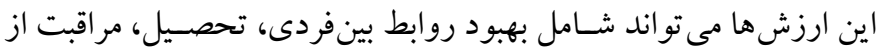

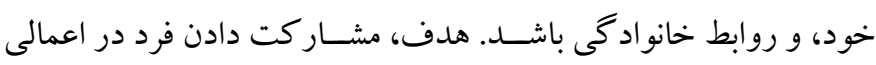

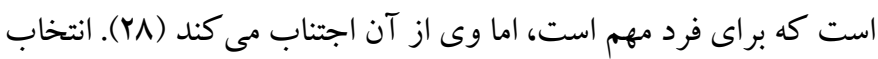

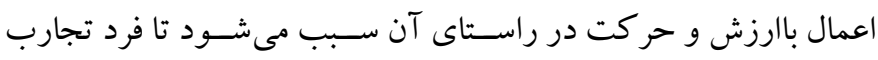

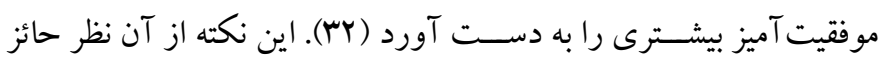

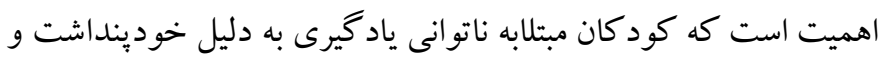
اعتمادبه خود آسيبديده، تجارب موفقيت آميز كمترى را تجربه مى كنند؛ بنابراين حركت در راستاى اعمال بارزش و كسب تجارب موفقيت آميز

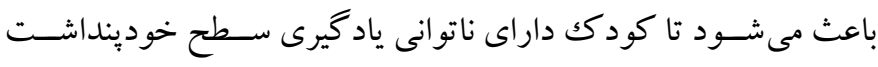

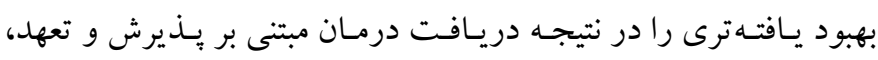

$$
\text { بهدست آورد. }
$$

يـافته دوم اين بزوهش نشــان داد كه درمان مبتنى بر بذيرش و تعهد

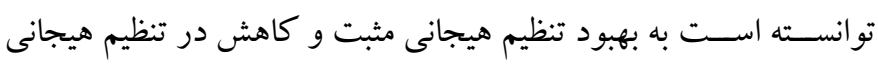

\section{جدول ع: ميانكينهاى تعديلشده متغير هاى وابسته}

\begin{tabular}{|c|c|c|c|}
\hline خطاى استدارد & ميانكين & & متغير \\
\hline$\cdot / V^{F}$ & $\Delta \mu / \cdot V$ & كروه آزمايش & \\
\hline$\cdot / V^{F}$ & $\mathrm{rq} / \mathrm{\wedge \Delta}$ & كروه گواه & يس آزمون تنظيم هيجانى مثبت \\
\hline$\cdot 191$ & $r \cdot / v \Delta$ & كروه آزمايش & \\
\hline .191 & $F \cdot / v \wedge$ & كروه كواه & يس آزمون تنظيم هيجانى منفى \\
\hline $1 / T V$ & $F \Delta / \Delta \Lambda$ & كروه آزمايش & \\
\hline $1 / Y V$ & rN/M & گروه گ گواه & خودينداشت \\
\hline
\end{tabular}

جنانكه از نتايج جدول \& مشـخص اسـت نمرات ميانگين تعديل شــه

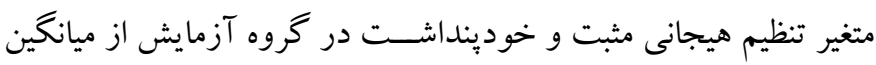
نمرات گروه گواه بيشتر است، اين در حالى است كه ميانكين تعديل شده

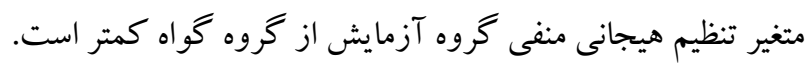

\section{بحث و نتيجه كيرى}

يُزوهش حاضـر با هدف بررسى اثربخشى درمان مبتنى بر بذيرش و تعهد

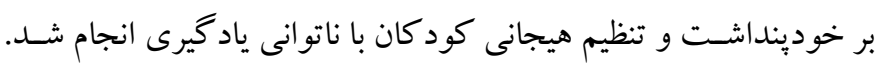

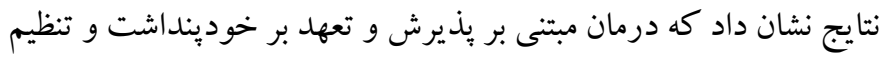
هيجانى مثبت و منفى كود كان داراى ناتوانى ياد گيرى خاص تأثير معنادار

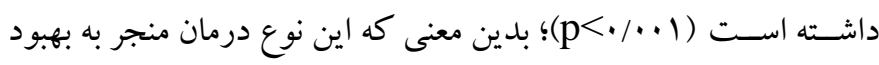
خودينداشـت و تنظيم هيجانى مثبت اين كود كان منجر شــده و همجنين

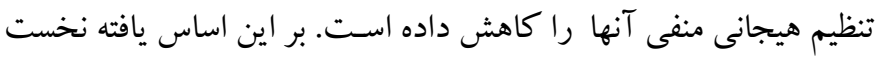

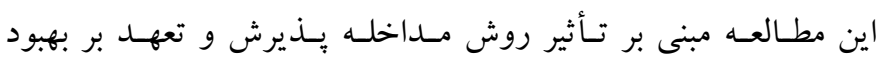

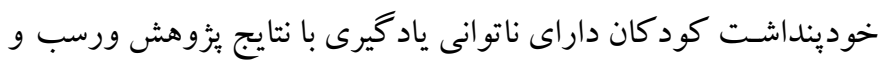

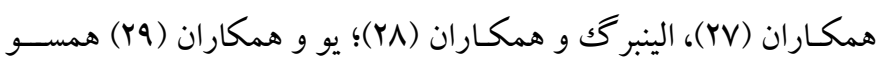

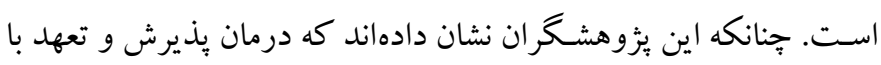

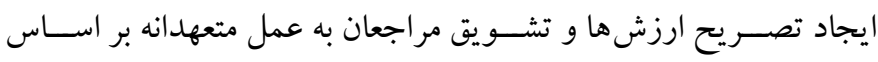

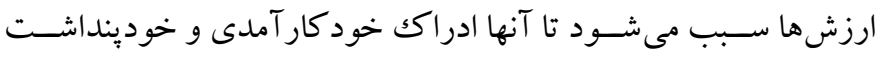

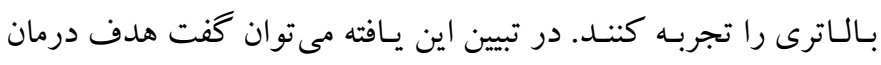
مبتنى بر روى آورد يذيرش و تعهد به مواردى مانند كاهش، تنظيم و يا از

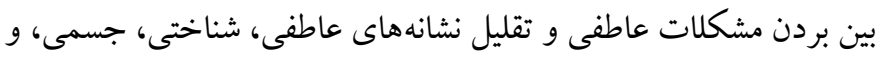

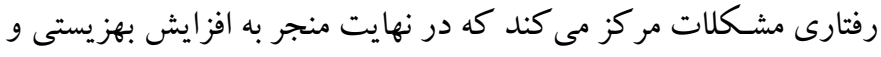

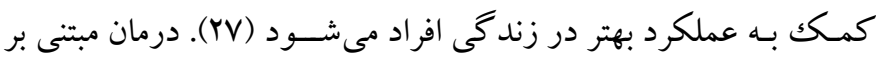

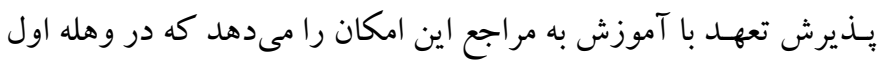


شـدت مشـكلات مى شـوند، رها شوند كه همين موضوع در نهايت باعث بهبود تنظيم هيجانى مى شود.

بزؤهش حاضـر، همانند هر مطالعه ديخر محدوديت هايى را به همرد اه داشـته اسـت. مححدود بودن نتايج يزوهش به دوره تحصيلى و دامنه سنى

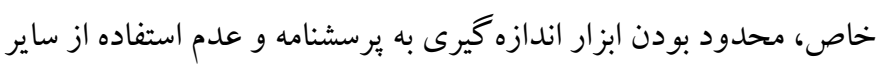

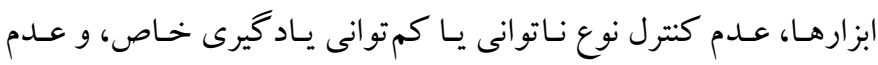

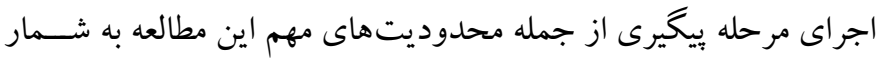

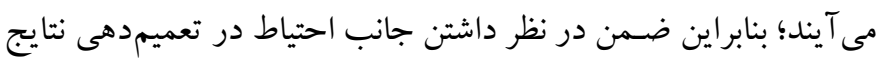

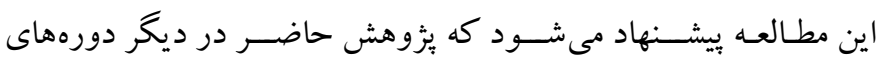

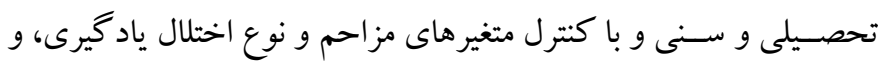

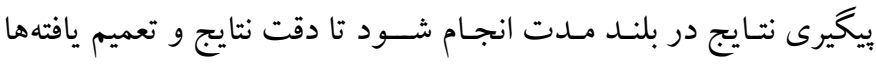

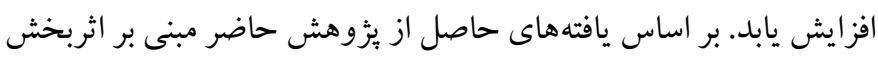

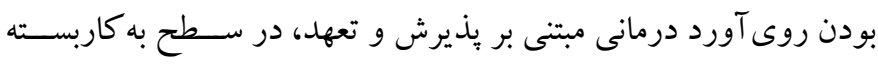

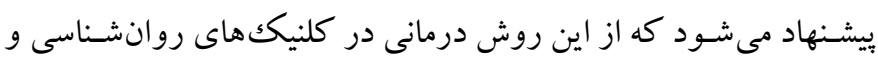

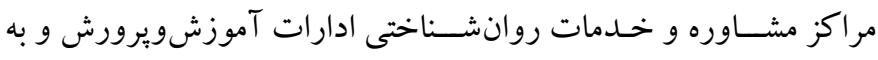
خصوص هسته مشاوره مستقر در مدارس استفاده شود. همجينين بيشنهاد

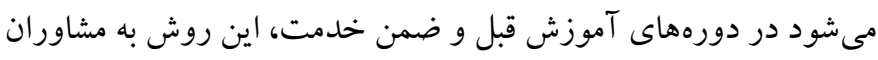

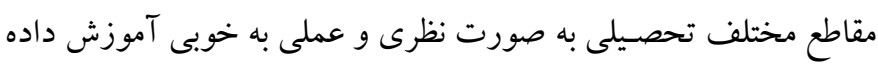

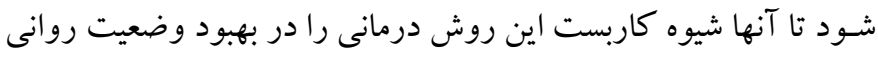

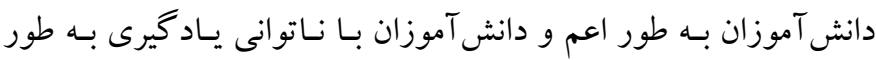
خاص، بياموزند.

تشكر و قدردانى: اين مطالعه بهصورت مستقل اجرا شده است. مجوز اجراى

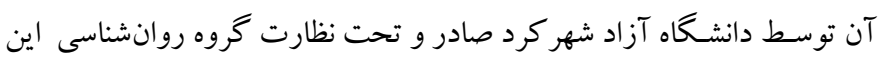
دانشكاه انجام شده است. بدينوسيله از كود كان حاضر در اين مطالعه و و والدين

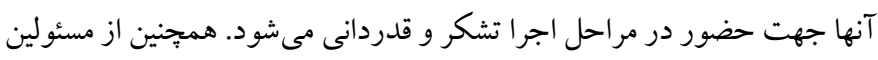

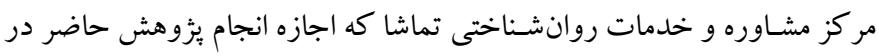
آن محل را فراهم كردند، تقدير و تشكر مى مشود.

تعارض منافع: در اين يُزوهش هيج گونه تعارض منافعى توســ نويسـند كان

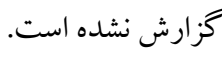

منفى كود كـان داراى ناتوانى ياد كيرى منجر شـــود. اين يافته با يافتهاى

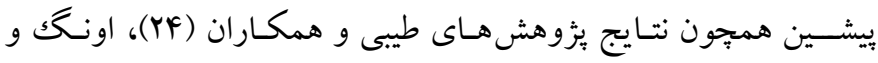

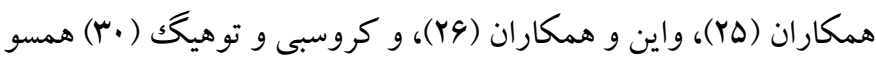

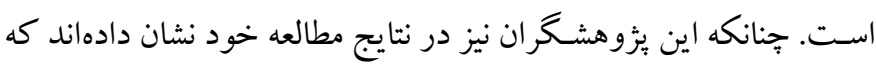

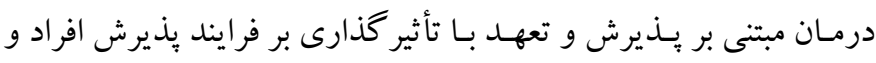

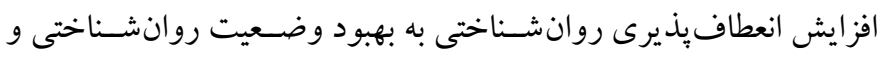

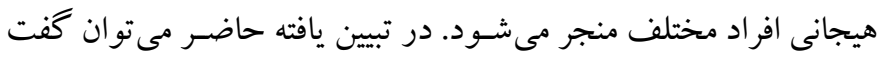

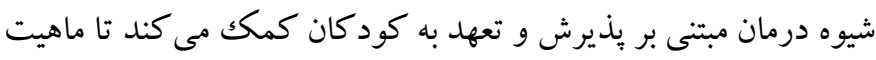

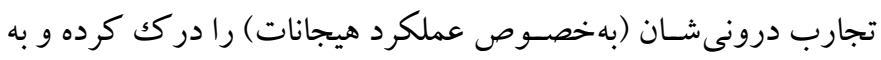
طور منطقى بفهمند. اين فرايند سـبب مىشـود تا آنها با يذيرش هيجانات

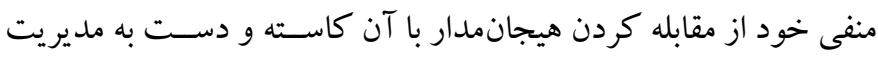

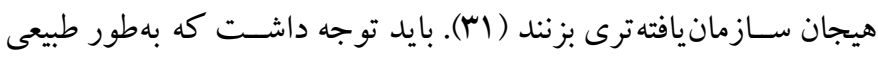

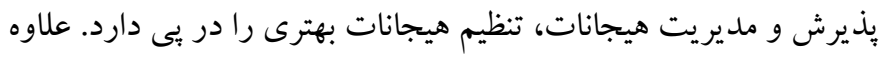
بر اين بايد در درمان بذيرش و تعهد تجارب ناخواسته حذف مى شود كه

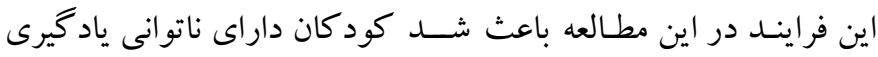

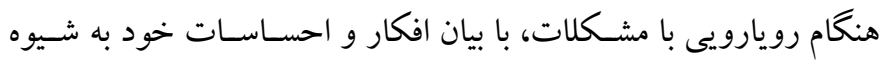

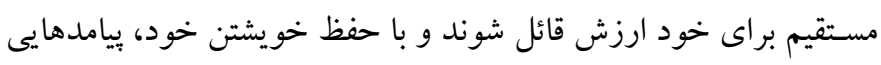

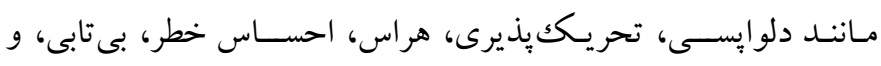

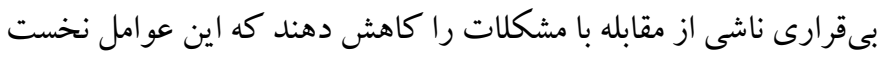
باعث حفظ سـلامتى و انرزى و بهبود عملكرد در مقابله با مشـكلات مخاطرهآميز، و در نهايت باعث بهبود تنظيم هيجانى مىشـوند (Y) (Y). در

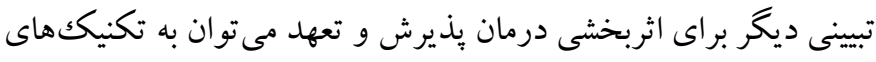
اين روش هميجون تصـريح ارزشها و عمل متعهدانه اشــاره كرد (بسان).

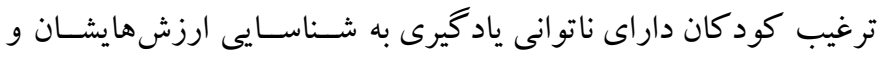

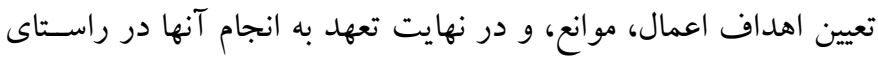
دستيابى به اهداف و حركت در مسير ارزشها با وجود مشكلات، باعث

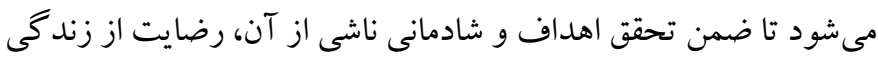

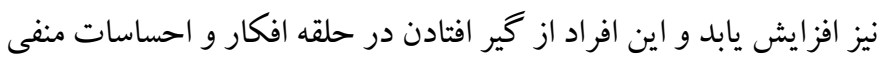

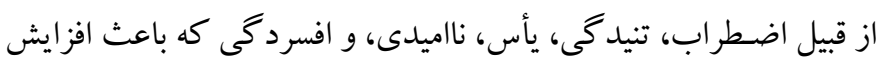




\section{References}

1. Sandy PT. The use of observation on patients who selfharm: Lessons from a learning disability service. Health SA Gesondheid. 2016; 21: 253-260. [Link]

2. Afeli SA. Academic accommodation strategies for pharmacy students with learning disabilities: What else can be done? Curr Pharm Teach Learn. 2019; 11 (8): 751-756. [Link]

3. Zhang S, Liu J, Wang J, Xia X, Zhang L, Liu L, Jiang $\mathrm{T}$. Developing and validating the learning disabilities screening scale in Chinese elementary schools. Inter J Edu Res. 2019; 96: 91-99. [Link]

4. Maag JW, Reid R. Depression among students with learning disabilities: Assessing the risk. J Learn Disabil. 2006; 39(1): 3-10. [Link]

5. Giuliani F, Jacquemettaz M. Animal-assisted therapy used for anxiety disorders in patients with learning disabilities: An observational study. Eur J Integr Med. 2017; 14: 13-19. [Link]

6. Mafra H. Development of learning and social skills in children with learning disabilities: an educational intervention program. Procedia Soc Behav Sci. 2015; 209: 221-228. [Link]

7. Wiener J. Do peer relationships foster behavioral adjustment in children with learning disabilities? Learn Disabil Q. 2004; 27(1): 21-30. [Link]

8. Power A, Bartlett R. Ageing with a learning disability: Care and support in the context of austerity. Soc Sci Med. 2019; 231: 55-61. [Link]

9. Floyd FJ, Olsen DL. Family-peer linkages for children with intellectual disability and children with learning disabilities. J Appl Dev Psychol. 2017; 52: 203-211. [Link]

10. Crane N, Zusho A, Ding Y, Cancelli A. Domainspecific metacognitive calibration in children with learning disabilities. Contemp Educ Psychol. 2017; 50: 72-79. [Link]

11. $\mathrm{Mu} \mathrm{GM}, \mathrm{Hu} \mathrm{Y}$, Wang Y. Building resilience of students with disabilities in China: The role of inclusive education teachers. Teach Teach Educ. 2017; 67: 125-134. [Link]

12. Chambrier A-F, Zesiger P. Is a fact retrieval deficit the main characteristic of children with mathematical learning disabilities? Acta Psychol. 2018; 190: 95102. [Link]

13. Tong $X$, Leung WWS, Tong $X$. Visual statistical learning and orthographic awareness in Chinese children with and without developmental dyslexia. Res Dev Disabil. 2019; 92: 103443. [Link]
14. Brabcová D, Zárubová J, Kohout J, Jošt J, Kršek P. Effect of learning disabilities on academic selfconcept in children with epilepsy and on their quality of life. Res Dev Disabil. 2015; 45-46: 120-128. [Link]

15. Gorges J, Neumann P, Wild E, Stranghöner D, LütjeKlose B. Reciprocal effects between self-concept of ability and performance: A longitudinal study of children with learning disabilities in inclusive versus exclusive elementary education. Learn Individ Differ. 2018; 61: 11-20. [Link]

16. Danesh E, Manavi Shad M, Khoushabi K, Hasanzadeh Tavakoli MR. The impact anger level and childrearing styles of mothers on self-concept of their children with or without LD. Journal of Family Research. 2014; 10(2): 175-196. [Persian]. [Link]

17. Paulus M, Licata M, Gniewosz B, Sodian B. The impact of mother-child interaction quality and cognitive abilities on children's self-concept and selfesteem. Cogn Dev. 2018; 48: 42-51. [Link]

18. Dehghani Y, Golestaneh SM, Zangouei S. The effectiveness of emotion regulation training on academic burnout, social acceptance and affective control of students with learning disabilities. Quarterly of Applied Psychology. 2018; 12 (2): 163-182. [Persian]. [Link]

19. Bryan T, Burstein K, Ergul C. The social-emotional side of learning disabilities: A science-based presentation of the state of the art. Learn Disabil Q. 2004; 27(1): 45-51. [Link]

20. Aldao A, Nolen-Hoeksema S, Schweizer S. Emotionregulation strategies across psychopathology: A metaanalytic review. Clin Psychol Rev. 2010; 30(2): 217237. [Link]

21. $\mathrm{Li} \mathrm{D}, \mathrm{Li} \mathrm{D}, \mathrm{Wu} \mathrm{N}$, Wang $\mathrm{Z}$. Intergenerational transmission of emotion regulation through parents' reactions to children's negative emotions: Tests of unique, actor, partner, and mediating effects. Child Youth Serv Rev. 2019; 101: 113-122. [Link]

22. Malesza M. Stress and delay discounting: The mediating role of difficulties in emotion regulation. Pers Individ Dif. 2019; 144: 56-60. [Link]

23. Kraaij V, Garnefski N. The behavioral emotion regulation questionnaire: development, psychometric properties and relationships with emotional problems and the cognitive emotion regulation questionnaire. Pers Individ Dif. 2019; 137: 56-61. [Link]

24. Tayebi Naieni P, Mohammad-Khani S, Akbari M, Abedi M. The effectiveness of acceptance and commitment therapy on psychological flexibility in children with obsessive-compulsive disorder. 
Quarterly Journal of Child Mental Health. 2017; 4(3): 91-106. [Persian]. [Link]

25. Ong CW, Lee EB, Krafft J, Terry CL, Barrett TS, Levin ME, et al. A randomized controlled trial of acceptance and commitment therapy for clinical perfectionism. J Obsessive Compuls Relat Disord. 2019; 22: 100444. [Link]

26. Wynne B, McHugh L, Gao W, Keegan D, Byrne K, Rowan C, et al. Acceptance and commitment therapy reduces psychological stress in patients with inflammatory bowel diseases. Gastroenterology. 2019; 156(4): 935-945.e1. [Link]

27. Wersebe H, Lieb R, Meyer AH, Hoyer J, Wittchen H$\mathrm{U}$, Gloster AT. Changes of valued behaviors and functioning during an acceptance and commitment therapy intervention. J Contextual Behav Sci. 2017; 6(1): 63-70. [Link]

28. Eilenberg T, Hoffmann D, Jensen JS, Frostholm L. Intervening variables in group-based acceptance \& commitment therapy for severe health anxiety. Behav Res Ther. 2017; 92: 24-31. [Link]

29. Yu L, Norton S, McCracken LM. Change in "self-ascontext" ("perspective-taking") occurs in acceptance and commitment therapy for people with chronic pain and is associated with improved functioning. J Pain. 2017; 18(6): 664-672. [Link]

30. Crosby JM, Twohig MP. Acceptance and commitment therapy for problematic internet pornography use: a randomized trial. Behav Ther. 2016; 47(3): 355-366. [Link]

31. Hofmann SG, Asmundson GJG. Acceptance and mindfulness-based therapy: New wave or old hat? Clin Psychol Rev. 2008; 28(1): 1-16. [Link]

32. McCracken LM, Sato A, Taylor GJ. A trial of a brief group-based form of acceptance and commitment therapy (act) for chronic pain in general practice: pilot outcome and process results. J Pain. 2013; 14(11): 1398-1406. [Link]
33. Roemer L, Orsillo SM, Salters-Pedneault K. Efficacy of an acceptance-based behavior therapy for generalized anxiety disorder: Evaluation in a randomized controlled trial. J Consult Clin Psychol. 2008; 76(6): 1083-1089. [Link]

34. Delavar A. Methods in psychology and educational sciences. Second edition. Tehran: Virayesh pub; 2012, p: 99. [Persian].

35. Willcutt EG, Boada R, Riddle MW, Chhabildas N, DeFries JC, Pennington BF. Colorado learning difficulties questionnaire: validation of a parent-report screening measure. Psychol Assess. 2011; 23(3): 778791. [Link]

36. Sobhi N, Hajloo N, Gholamzadeh H. A comparison of learning styles, personality characteristics and academic performance of students with and without learning disabilities. Journal of Learning Disabilities. 2013; 2(4): 82-102. [Persian]. [Link]

37. Garnefski N, Kraaij V. Cognitive emotion regulation questionnaire - development of a short 18-item version (CERQ-short). Pers Individ Dif. 2006; 41(6): 1045-1053. [Link]

38. Yousefi F. The relationship of cognitive emotion regulation strategies with depression and anxiety in students of special middle schools for talented students in Shiraz. Journal of Exceptional Children. 2007; 6(4): 871-892. [Persian]. [Link]

39. Campbell JD, Trapnell PD, Heine SJ, Katz IM, Lavallee LF, Lehman DR. Self-concept clarity: Measurement, personality correlates, and cultural boundaries. J Pers Soc Psychol. 1996; 70(1): 141-156. [Link]

40. Marsh HW. Influences of internal and external frames of reference on the formation of math and English selfconcepts. J Educ Psychol. 1990; 82(1): 107-116. [Link]

41. Saatchi M, Kamkari K, Askarian M. Psychological tests. First Edition. Tehran: Virayesh Pub; 2015, p: 74. [Persian]. 